\title{
Decreased expression of GST pi is correlated with a poor prognosis in human esophageal squamous carcinoma
}

\author{
Zhihui Wang 1,2, Wei He1,2, Guanrui Yang*1,3, Junsheng Wang4 , Zhong Wang 4 , Jahn M Nesland², Ruth Holm² and \\ Zhenhe Suo*2
}

\begin{abstract}
Background: Glutathione S-transferase pi (GST pi) is a subgroup of GST family, which provides cellular protection against free radical and carcinogenic compounds due to its detoxifying function. Expression patterns of GST pi have been studied in several carcinomas and its down-regulation was implicated to be involved in malignant transformation in patients with Barrett's esophagus. However, neither the exact role of GST pi in the pathogenesis nor its prognostic impact in squamous esophageal carcinoma is fully characterized.

Methods: Immunohistochemistry was used to investigate GST pi expression on 153 archival squamous esophageal carcinoma specimens with a GST pi monoclonal antibody. Statistic analyses were performed to explore its association with clinicopathological factors and clinical outcome.

Results: The GST pi expression was greatly reduced in tissues of esophageal carcinomas compared to adjacent normal tissues and residual benign tissues. Absent of GST pi protein expression in cytoplasm, nuclear and cytoplasm/nucleus was found in 51\%, 64.7\% and $48 \%$ of all the carcinoma cases, respectively. GST pi deficiency in cytoplasm, nucleus and cytoplasm/nucleus was significantly correlated to poor differentiation ( $p<0.001, p<0.001$ and $p<0.001$, respectively). UICC stage and T stage were found significantly correlated to negative expression of GST pi in cytoplasm $(p<0.001$ and $p=0.004$, respectively) and cytoplasm/nucleus ( $p=0.017$ and $p=0.031$, respectively). In univariate analysis, absent of GST pi protein expression in cytoplasm, nucleus and cytoplasm/nucleus was significantly associated with a shorter overall survival ( $p<0.001, p<0.001$ and $p<0.001$, respectively), whereas only GST pi cytoplasmic staining retained an independent prognostic significance $(p<0.001)$ in multivariate analysis.

Conclusions: Our results show that GST pi expression is down regulated in the squamous esophageal carcinoma, and that the lack of GST pi expression is associated with poor prognosis. Therefore, deficiency of GST pi protein expression may be an important mechanism involved in the carcinogenesis and progression of the squamous esophageal carcinoma, and the underlying mechanisms leading to decreased GST pi expression deserve further investigation.
\end{abstract}

\section{Background}

Esophageal cancer (EC) ranks the third among most common cancer of the digestive tract and the seventh leading cause of cancer-related deaths worldwide [1,2]. With new cases accounting for nearly half new cases of the world per year, China is among the highest incidence

\footnotetext{
*Correspondence: yangguanrui@yahoo.com.cn, zhenhes@medisin.uio.no 1 Department of Oncology, The First Affiliated Hospital of Zhengzhou University, Medical College of Zhengzhou University, Zhengzhou, China 2 Department of Pathology, Oslo University Hospital, Ullernchausseen 70, Oslo, Norway

Full list of author information is available at the end of the article
}

areas [3]. EC is usually diagnosed at late stages with a five-year survival rate of only $5-10$ percent $[3,4]$. Surgical resection is believed to offer the best chance for longterm survival compared to other therapies such as radioand chemotherapy, used alone or in combination as adjuvant treatments [3,5-8]. However, surgical resection is often unavoidably followed by considerable compromised life-quality. Therefore, individualized therapy which benefits patients with the highest treatment efficiency yet the least morbidity is increasing stringent for treatment. To pave the way for it, it is important to identify prognos- 
tic markers and predictors of significance value in this tumor [9].

Glutathione S-transferases (GSTs), a supergene family with at least four distinct isoforms $(\alpha, \mu, \pi, \theta)$ identified in human, are involved in the metabolism of xenobiotic compounds in the phase II detoxification [10-12]. They are capable of converting a variety of electrophilic and hydrophobic compounds into more soluble, more easily excretable compounds through catalyzing them in conjunction with glutathione [10]. As numerous potentially toxic carcinogenic compounds, being electrophilic and hydrophobic, are detoxified in this way, GSTs is believed to play an important role in cancer prevention $[13,14]$. Down-regulation of GSTs has been reported as an increased risk for developing gastric, colorectal, and lung cancer [15-17]. Decreased GST enzyme activity in the gastrointestinal track is implicated with a raised tumor incidence [2].

GST pi, the predominant isoform in the normal squamous esophagus epithelium [18], is present in a wide range of normal human tissues $[18,19]$, as well as in various malignant tumors of urinary, digestive, and respiratory tracts [20-24]. No consensus has been achieved yet regarding to the association between GST pi expression and malignant transformation. Some studies suggest an increased expression of GST pi as an indicator for premalignant and malignant changes [25,26]; Whereas, in others, GST pi expression is indicated to be a marker of carcinogen exposure in the upper aerodigestive tract [2730]. Meanwhile, in some studies, loss of GST pi expression is suggested as a phenotype associated with carcinogenesis [31,32].

As to the alternation of GST pi in development of esophageal carcinoma, several studies have been performed on Barrett's metaplasia and adenocarcinoma with results suggesting deficiency of GST pi may contribute to an increased cancer risk [2,33,34]. However, limited knowledge is available in terms of GST pi alternation in squamous esophageal carcinoma, as well as its connection with clinical parameters. Therefore, in the present study, we report results of an immunohistochemical survey of GST pi in 153 squamous esophageal carcinoma cases with a long term follow-up. Our study confirms a down-regulated GST pi expression in this type of tumor, and demonstrates the deficiency of GST pi protein expression is significantly associated with a shorter overall survival.

\section{Methods}

\section{Patient materials}

One hundred and fifty-three patients composed by 93 men and 60 women with esophageal squamous cell carcinoma, whom underwent potentially curative surgery during 1989-1994 at Anyang Tumor Hospital, Henan, China, were enrolled in this retrospective study. The median age at diagnosis was 56.4 years (range 33-73 years). No preoperative chemotherapy and radiotherapy were given. All tumors were staged according to International Union against Cancer (UICC) 2003 Classification. One hundred (65.4\%) cases were classified as stage II and 53 (34.6\%) cases as III. All patients were followed up until death or 31. May, 2004. Ninety-seven (63.4\%) patients died of esophageal cancer. The median follow-up time for all patients was 90 months (range 1-155 months). The follow-up and data analyses were performed by researchers from both sides of this international cooperation project, Anyang Tumor Hospital, China and The Norwegian Radium Hospital, Norway. Patients' information included tumor size, TNM staging, pathologic grade, demographic data and mortality. Study approval was given by the Regional Committee for Medical Research Ethics in Norway.

Specimens removed from surgery were fixed in formalin, processed and embedded in paraffin blocks for diagnosis and research use. Histological specimens were reviewed by two of the co-authors (Z.S and J.M.N) who had no access to clinical information. The detailed description as to the tumor characteristics was listed in Table 1.

\section{Tissue array method}

Multi-tissue array paraffin blocks were produced by a MTA-1 manual tissue arrayer (Beecher Instruments Inc., Sun Prairie, WI, U.S.A), before $5 \mu \mathrm{m}$ paraffin sections were cut and underwent the Hematoxyline and Eosin (H\&E) staining. After evaluation, two representative tumor areas and one stroma area on each sample were selected, respectively. The chosen regions were then removed from the original paraffin block to a recipient paraffin block by using the hollow-cored needles with the core-diameter of $0.6 \mathrm{~mm}$. By this way, the pin-picked chosen tissues were arrayed on the recipient paraffin block. Finally, five $\mu \mathrm{m}$ sections made from those recipient paraffin blocks were cut and mounted on the charged Super-Frost Plus glass slides, and ready for immunohistochemistry analysis after pre-dried at $60 \hat{\mathrm{A}}^{\circ} \mathrm{C}$ in an oven for 2-4 hours. For samples on which the representative areas were failed to choose for tissue array, five $\mu \mathrm{m} \mathrm{sec-}$ tions from the whole tissue paraffin blocks underwent immunohistochemical analysis as well.

\section{Immunohistochemical method}

Dako EnVision $^{\text {Tw }}$ + System, Peroxidase (DAB) (K4007, Dako Corporation, CA, and U.S.A) was employed for immunostaining. Sections were first deparaffinized in xylene and microwaved in $10 \mathrm{mM}$ citrate buffer $\mathrm{pH} 6.0$ to unmask the epitopes, and then treated with $0.3 \%$ hydrogen peroxide $\left(\mathrm{H}_{2} \mathrm{O}_{2}\right)$ for 5 min to block the endogenous 
Table 1: GST pi immunostaining in relation to clinicopathological variables

\begin{tabular}{|c|c|c|c|c|c|c|c|c|c|c|}
\hline \multirow[t]{2}{*}{ Variables } & \multirow{2}{*}{$\begin{array}{l}\text { Total } \\
\mathrm{N}(\%)\end{array}$} & \multicolumn{3}{|c|}{ Cytoplasm } & \multicolumn{3}{|c|}{ Nucleus } & \multicolumn{3}{|c|}{ Cytoplasm and Nucleus } \\
\hline & & $\begin{array}{c}\text { Negative } \\
\text { (\%) }\end{array}$ & Positive & $p^{1}$ & $\begin{array}{c}\text { Negative } \\
\text { (\%) }\end{array}$ & Positive & $p^{1}$ & $\begin{array}{c}\text { Negative } \\
\text { (\%) }\end{array}$ & Positive & $p^{1}$ \\
\hline Age & & & & 0.019 & & & 0.405 & & & 0.060 \\
\hline$<51$ & $48(31)$ & $18(38)$ & 30 & & $28(58)$ & 20 & & $19(40)$ & 29 & \\
\hline $51-60$ & $52(34)$ & $34(65)$ & 18 & & $37(71)$ & 15 & & $32(62)$ & 20 & \\
\hline$>60$ & $53(35)$ & $26(49)$ & 27 & & $34(64)$ & 19 & & $23(43)$ & 30 & \\
\hline gender & & & & 0.185 & & & 0.302 & & & 0.136 \\
\hline Male & $93(61)$ & $43(46)$ & 50 & & $57(61)$ & 36 & & $40(43)$ & 53 & \\
\hline Female & $60(39)$ & $35(58)$ & 25 & & $42(70)$ & 18 & & $34(57)$ & 26 & \\
\hline Histological grade & & & & $<0.001$ & & & $<0.001$ & & & $<0.001$ \\
\hline Well & $53(35)$ & $13(25)$ & 40 & & $22(42)$ & 31 & & $12(23)$ & 41 & \\
\hline Moderate & $60(39)$ & $38(63)$ & 22 & & $45(75)$ & 15 & & $36(60)$ & 24 & \\
\hline Poor & $40(26)$ & $27(68)$ & 13 & & $32(80)$ & 8 & & $26(65)$ & 14 & \\
\hline Location & & & & 0.232 & & & 0.929 & & & 0.995 \\
\hline Upper & $14(9)$ & $5(36)$ & 9 & & $9(64)$ & 5 & & $7(50)$ & 7 & \\
\hline Middle & $101(66)$ & $47(47)$ & 54 & & $67(66)$ & 34 & & $49(49)$ & 52 & \\
\hline Lower & $35(23)$ & $21(60)$ & 14 & & $22(63)$ & 13 & & $17(49)$ & 18 & \\
\hline Missing & $3(2)$ & 2 & 1 & & 2 & 1 & & 2 & 1 & \\
\hline Size & & & & 0.238 & & & 0.973 & & & 0.843 \\
\hline$\leq 30 \mathrm{~mm}$ & $25(16)$ & $11(44)$ & 14 & & $17(68)$ & 8 & & $11(44)$ & 14 & \\
\hline $31-60 \mathrm{~mm}$ & $105(69)$ & $59(56)$ & 46 & & $70(67)$ & 35 & & $53(51)$ & 52 & \\
\hline$>60 \mathrm{~mm}$ & $14(9)$ & $5(36)$ & 9 & & $9(64)$ & 5 & & $7(50)$ & 7 & \\
\hline Missing & $9(6)$ & 3 & 6 & & 4 & 5 & & 3 & 6 & \\
\hline Lymph node metastasis & & & & 0.090 & & & 0.727 & & & 0.398 \\
\hline- & $99(65)$ & $45(46)$ & 54 & & $63(64)$ & 36 & & $45(46)$ & 54 & \\
\hline+ & $54(35)$ & $33(61)$ & 21 & & $36(67)$ & 18 & & $29(54)$ & 25 & \\
\hline UICC stage & & & & $<0.001$ & & & 0.377 & & & 0.017 \\
\hline ॥ & $100(65)$ & $40(40)$ & 60 & & $62(62)$ & 38 & & $41(41)$ & 59 & \\
\hline III & $53(35)$ & $38(71)$ & 15 & & $37(70)$ & 16 & & $33(62)$ & 20 & \\
\hline T stage & & & & 0.004 & & & 0.126 & & & 0.031 \\
\hline$I+I I$ & $44(29)$ & $14(32)$ & 30 & & $23(52)$ & 21 & & $14(32)$ & 30 & \\
\hline III & $100(65)$ & $57(57)$ & 43 & & $70(70)$ & 30 & & $54(54)$ & 46 & \\
\hline IV & $9(6)$ & $7(78)$ & 2 & & $6(67)$ & 3 & & $3(33)$ & 6 & \\
\hline
\end{tabular}

1Pearson chi-square

peroxidase. Afterwards, monoclonal glutathione-S-transferanse pi antibody (clone 353-10, 1:50, from Acris Antibodies $\mathrm{GmbH}$, Germany) was applied on the sections for $30 \mathrm{~min}$ at room temperature, followed by an incubation with the horzeradish peroxidase (HRP) labeled polymer conjugated to goat anti-mouse IgG for $30 \mathrm{~min}$ at room temperature. Sections were then incubated with 3'3diaminobenzidine tetrahydrochloride (DAB) for $10 \mathrm{~min}$, and counterstained with hematoxylin, dehydrated and mounted in Diatex before evaluation.

Immunostaining of each section was semiquantitatively scored for both intensity (1, absent/weak; 2 , moderate; 3 , strong) and extent of staining (percentage of the positive tumor cells: $1,<10 \% ; 2,10-50 \% ; 3,>50 \%)$. The scoring results of intensity and extent were multiplied to give a composite score ranging from 1 to 9 for each section. 
Examination of immunostaining was performed by two independent observers (Z.W and Z.S) with no knowledge of patients outcome. All discordant scores were reviewed until final agreements were obtained.

\section{Statistical analyses}

The associations between GST pi protein expression and clinicopathologic variables were evaluated by the Person $X^{2}$ test. The Kaplan - Meier method were employed to estimate the survival rate. A Cox proportional hazards regression model was formed to perform multivariate evaluation of survival rates, after the fulfillment of proportional hazard assumption of variables was evaluated by STATA statistical software package (Stata 10.0, collage station, TX). The calculation was performed by usage of the SPSS 16.0 statistical software package (SPSS, Chicago, IL), and $p$ â\%o 0.05 was considered as statistical significance.

\section{Results}

\section{Frequency of GST pi protein expression}

The majority of cases contained adjacent normal tissues and residual benign tissues, on which strong positive staining presented and served as the internal control for both cytoplasm and nucleus. Immunostaining in adjacent normal tissues and residual benign tissues was found in parabasal, middle and top layers of the esophageal epithelium (Figure 1a and 1b).

In esophageal carcinomas, positive immunostaining in either cytoplasm (Figure 1c), or nucleus (Figure 1d), or cytoplasm/nucleus (Figure 1e) was discoved in 75 (49\%), 54 (35.3\%), and $79(51.6 \%)$ cases, respectively. Negative immunostaining for GST pi in either cytoplasam (Figure 1d), or nucleus (Figure 1c), or both cytoplasma and nucleus (Figure 1f) was found in 78 (51\%), 99 (64.7\%), and 74 (48.4\%) cases, respectively. The summarized GST pi immunostaining score was listed in Table 2.

\section{GST pi immunostaining in relation to clinicopathological parameters and patients survival}

GST pi immunostaining status in relation to clinicopathological parameters was summarized in Table1. Negative expression of GST pi in cytoplasm, nucleus and cytoplasm/nucleus was significantly correlated to high histological grade $(p<0.001, p<0.001$ and $p<0.001$, respectively). UICC stage and T stage were found significantly correlated to negative expression of GST pi in cytoplasm ( $p<0.001$ and $p=0.004$, respectively) and cytoplasm/nucleus ( $p=0.017$ and $p=0.031$, respectively). No significant associations were found between GST pi expression levels and age, gender, location, tumor size and lymph node metastasis.

In evalution of proportional hazard assumption of variables, it was found that variables including UICC stage, $\mathrm{T}$ stage and GST pi staining in cytoplasm, nucleus and cytoplasm/nucleus were qualified for such analysis, and all survival curves did not cross substantially. Histological grade did not fulfill proportional hazard assumption, but was used in multivariate analysis as a strata variate. In univariate analysis, high UICC stage $(p<0.001)$, high $\mathrm{T}$ stage $(p<0.001$ and $p=0.001)$, and GST pi staining in cytoplasm, nucleus and cytoplasm/nucleus ( $p<0.001, p<$ 0.001 and $p<0.001$ respectively) were associated with poor overall survival (Figure 2). In multivariate analysis with histological grade as a strata variate, only $\mathrm{T}$ stage and GST pi cytoplasmic staining retained independent prognostic significance $(p<0.001, p<0.001$ and $p<$ 0.001 , respectively) (Table 3 ).

\section{Discussion}

Previously, GST pi expression in tissue and serum was suggested as a cancer marker in several studies [10,26], with results showing inconsistent GST pi expression patterns in various carcinomas. In gastric cancer, an increased serum GST pi was hypothesized to correlate to the advanced stage, and its expression in tissue was found inversely correlated to survival [35]. In precancerous foci of colorectal polyps, an increased GST pi expression presented in the high grade adenoma [36]. However, in prostate adenocarcinoma, down-regulation of GST pi was observed and the loss of GST pi expression was regarded as a phenotype associated with malignant transformation [31,37].

In esophageal carcinomas, many studies showed that down-regulation of GST pi expression was involved in malignant progression from Barrett's esophagus to esophageal adenocarcinoma [2,34]. The decreased GST pi expression was observed in Barrett's epithelium $[2,34,38]$, and lower GST pi mRNA levels were detected by Northern blot analysis and measurements of enzymatic activity [38-40]. These studies anticipated that the absence of this detoxifying enzyme may play an important role in development and progression of esophageal carcinoma $[38,41]$. However, a study on limited samples (53 samples from 19 patients) by Chandra et al. [2] argued that high GST pi expression connoted a poor prognosis. At the same time, the authors failed in finding statistical significant difference to the disease-free survival [2].

In our present study, down-regulated GST pi was observed in squamous esophageal carcinomas, a finding which is rather consistent with the esophageal carcinoma studies by Huang et al. [42] and Fu et al. [43]. Both Huang's and our study find that loss of GST pi expression is associated with clinicopathological factor of high histological grade. Furthermore, our results also demonstrate that the reduced GST pi expression is correlated to the overall survival, indicating that GST pi down-regulation is not only associated with esophageal tumorigenesis, a 


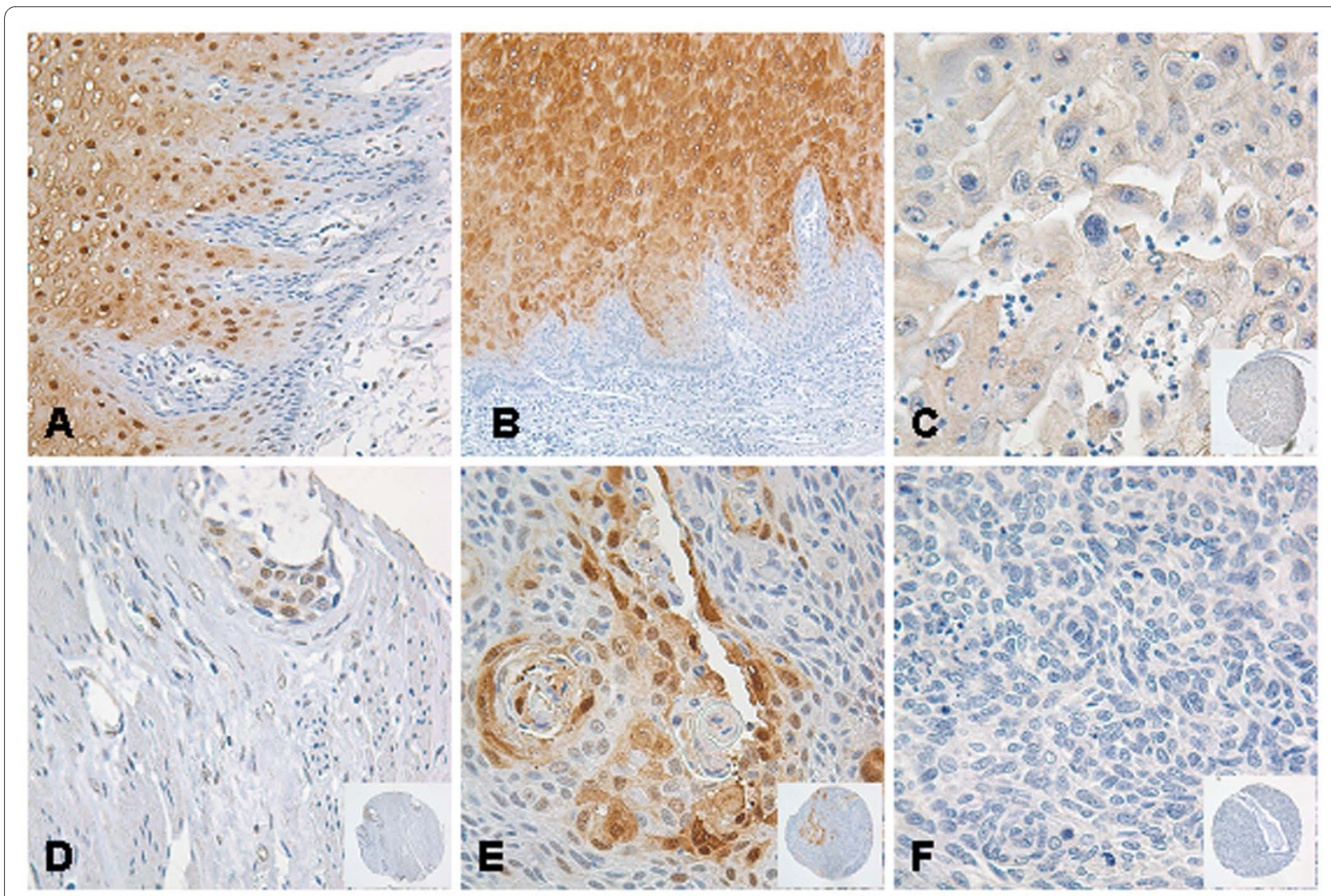

Figure 1 Expression of GST pi protein in squmous esophagus epithelium. Expression of GST pi protein in normal squamous esophagus epithelium (A) and (B). Expression of GST pi protein in esophageal squamous carcinoma with positive immunostaining in cytoplasm and negative in nucleus (C). Expression of GST pi protein in esophageal squamous carcinoma with negative immunostaining in cytoplasm and positive in nucleus (D). Expression of GST pi protein in esophageal squamous carcinoma with positive immunostaining in both cytoplasm and nucleus (E). Expression of GST pi protein in esophageal squamous carcinomas with negative immunostaining in both cytoplasm and nucleus (F). Original magnification: $\times 400$ (A, B); $\times$ $600(C-F) ; \times 200$ (pictures at lower right corner of C-F).

process with a variety of genetic and epigenetic alterations $[34,38,44]$, but also with esophageal tumor progression.

GST pi polymorphism has been suggested to be involved in alternation of GST pi enzyme activity. Van et al. [45] showed that the reduced GST pi enzyme activity in Barrett's esophagus was attribute to the expression of

\section{Table 2: Immunostaining results for GST pi}

\begin{tabular}{|c|c|c|c|c|c|c|}
\hline \multirow[t]{2}{*}{ Score } & \multicolumn{2}{|c|}{ Cytoplasm } & \multicolumn{2}{|c|}{ Nucleus } & \multicolumn{2}{|c|}{ Cytoplasm/nucleus } \\
\hline & $\mathbf{n}$ & $(\%)$ & $\mathbf{n}$ & $(\%)$ & $\mathbf{n}$ & (\%) \\
\hline 0 & 78 & $(51.0)$ & 99 & $(64.7)$ & 74 & $(48.4)$ \\
\hline 3 & 54 & $(35.3)$ & 43 & $(28.1)$ & 58 & (37.9) \\
\hline 6 & 21 & $(13.7)$ & 10 & (6.5) & 17 & (11.1) \\
\hline 9 & 0 & $(0)$ & 1 & $(0.7)$ & 4 & (2.6) \\
\hline Total & 153 & $(100.0)$ & 153 & $(100.0)$ & 153 & $(100.0)$ \\
\hline
\end{tabular}

GST pi b, a genotype encoding GST pi enzyme with a less activity, compared with GST pi a. Compton and coworkers [40] suggested that down-regulation of GST pi was second to the decreased GST pi mRNA level, which happened in transcription step due to gene interactions [38]. In addition, decreased level of GST pi was implied to connect with the epigenetic alternation, resulting in the transcriptional silence. Hypermethylation of $\mathrm{CpG}$ islands within promoter regions has been found in several genes, and has been implied to be responsible for down-regulation of their protein products [46-48]. Hypermethylation of GST pi gene, although happened at a low frequency, has been reported in esophageal adenocarcinomas [44]. Potential mechanisms accounting for down-regulation of GST pi in malignant transduction in Barrett's esophagus may take place in squamous esophageal carcinoma as well. We speculate that epigenetic alterations may happen in squamous esophageal carcinomas and results in a decreased GST pi expression in this type of tumor. 
Table 3: Relative risk (RR) of dying from esophageal squamous carcinoma

\begin{tabular}{|c|c|c|c|c|c|c|}
\hline \multirow[t]{2}{*}{ Variables } & \multicolumn{3}{|c|}{ Univariate analysis } & \multicolumn{3}{|c|}{ Multivariate analysis } \\
\hline & $\mathbf{R R}$ & $95 \% \mathrm{Cla}^{\mathrm{a}}$ & $p$ & $\mathbf{R R}$ & $95 \% \mathrm{Cla}^{\mathrm{a}}$ & $p$ \\
\hline UICC stage & 3.37 & $2.24-5.07$ & $<0.001$ & - & - & - \\
\hline T stage (III/I+ II) & 3.46 & $1.86-6.44$ & $<0.001$ & 3.94 & $2.22-7.01$ & $<0.001$ \\
\hline T stage (IV/I + II) & 4.85 & $1.98-11.91$ & 0.001 & 8.83 & $3.73-20.90$ & $<0.001$ \\
\hline GSTpi cytoplasmic staining & 5.63 & $3.50-9.06$ & $<0.001$ & 4.80 & $2.94-7.84$ & $<0.001$ \\
\hline GSTpi nucleus staining & 2.92 & $1.80-4.73$ & $<0.001$ & - & - & - \\
\hline GSTpi cytoplasmic/nucleus staining & 3.95 & $2.56-6.11$ & $<0.001$ & - & - & - \\
\hline
\end{tabular}

a95\% confidence interval

Limited knowledge is known whether an increased risk of cancer development is secondary to GST pi down-regulation or not, but some studies on esophagus have suggested that imbalance between redox and GST enzyme might get involved [2]. According to the study of Chandra et al. [2], redox molecular species may play double-edged roles. On one side, they could kill tumor cells by inducing cell apoptosis and/or through other mechanisms. On the other side, due to the redox-mediated damages on DNA molecules, they could initiate a cascade of mutational events which promoted the development or progression of malignancy.

Studies on NOân $\hat{A}^{\wedge \mathrm{m}}$, a redox molecular, have found that upper aerodigestive track malignancies strongly expressed the enzymatic machinery necessary to generate NOâ $\hat{a}^{\wedge m}$, in spite of its known physiologic roles on regulation of vascular blood flow and an assistance on killing infectious and malignant cells $[49,50]$. The prevalence expression of $\mathrm{NOâ}^{\wedge \mathrm{m}}$ in tumor cells indicated a potential high concentration of $\mathrm{NO}^{\wedge \mathrm{n}}$ in microenvironment of tumor $[1,33,51]$ raising concerns of mutagenesis due to breaking up the double-strand structure of DNA mole- cules [52]. However, effects of high NOân ${ }^{\text {тм }}$ levels can be counteracted by glutathione [53]. GST enzymes, by catalyzing glutathione to nucleophilic compounds, provide a key biochemical sink for free radicals and highly reactive molecules [2]. Lack of GST expression may lead to accumulation of redox-mediated DNA damages in cells, contributing to genome instability as a result of an imbalance between GST enzymes and redox species.

As to development and progression of squamous esophageal carcinoma, we speculate that lack or loss of GST pi protein expression may predispose a normal cell to undergo further genetic alternations, raising risks of malignant changes ultimately and even tumor progression.

\section{Conclusions}

The present study, by using immunohistochemistry on 153 cases, confirms that the expression of GST pi is down-regulated in squamous esophageal epithermal carcinomas and significantly associated with poor overall survival. Deficiency of GST pi protein expression may be an important mechanism involved in the carcinogenesis
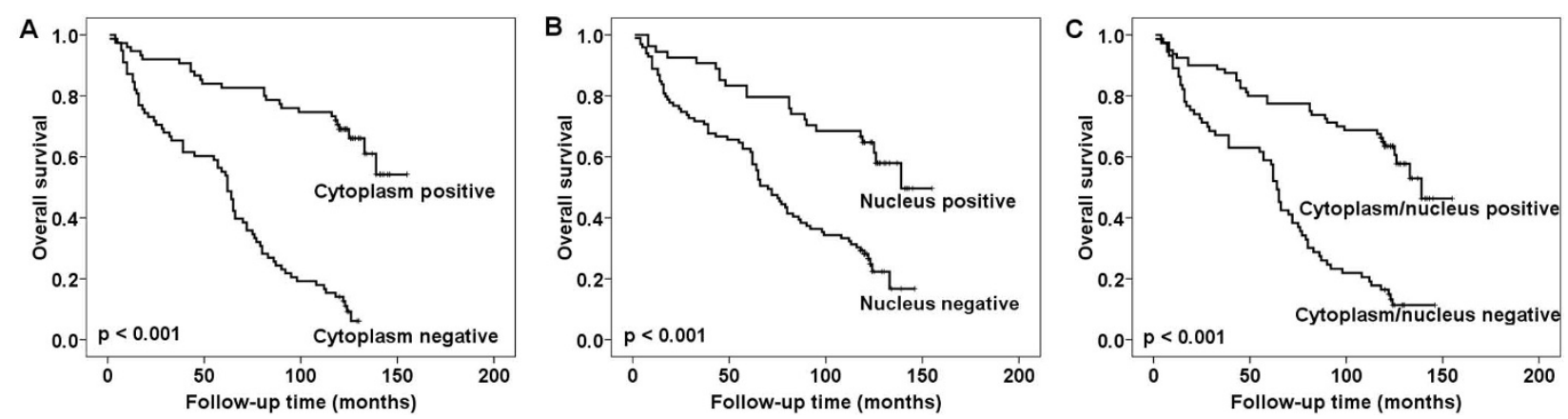

Figure 2 Survival curves using the Kaplan-Meier method. Kaplan-Meier curves drawn for the entire series ( $n=153$ ) based on GST pi protein expression levels in cytoplasm ( $p=0.001)$ (A). Kaplan-Meier curves drawn for the entire series ( $n=153)$ based on GST pi protein expression levels in nucleus ( $p<0.001)$ (B). Kaplan-Meier curves drawn for the entire series $(n=153)$ based on GST pi protein expression levels in cytoplasm/nucleus $(p=$ $0.001)(C)$. 
and progression of esophageal squamous carcinomas. Further studies are deserved to explore the underlying mechanisms leading to decreased GST pi expression in this type of tumor.

\section{Competing interests}

The authors declare that they have no competing interests.

\section{Authors' contributions}

ZW participated in the design of the study, carried out the immunohistochemical analysis, statistical and data analysis and draft the manuscript. WH participated in the design of the study, interpretation of data and manuscript revising. GY, JW and ZW were involved in the project design, collection of clinical data, interpretation of data and manuscript revising. JMN revised the manuscript critically. RH participated in statistical and data analysis and helped to draft the manuscript. ZS participated in the design of the study, statistical and data analysis and helped to draft the manuscript. All authors read and approved the final manuscript.

\section{Acknowledgements}

We thank Mette Førsund and Ellen Hellesylt for excellent technical support.

\section{Author Details}

'Department of Oncology, The First Affiliated Hospital of Zhengzhou University, Medical College of Zhengzhou University, Zhengzhou, China, 2Department of Pathology, Oslo University Hospital, Ullernchausseen 70, Oslo, Norway, ${ }^{3}$ Henan Institute of Medical Science, Medical College of Zhengzhou University, Zhengzhou, China and ${ }^{4}$ Department of Oncology, Anyang Tumor Hospital, Henan, China

Received: 27 November 2009 Accepted: 5 July 2010

Published: 5 July 2010

\section{References}

1. Bentz BG, Haines GK, Radosevich JA: Increased protein nitrosylation in head and neck squamous cell carcinogenesis. Head Neck 2000, 22:64-70.

2. Chandra RK, Bentz BG, Haines GK, Robinson AM, Radosevich JA: Expression of glutathione s-transferase pi in benign mucosa, Barrett's metaplasia, and adenocarcinoma of the esophagus. Head Neck 2002, 24:575-581.

3. Jiang JM, Zeng XJ, Chen JS, Li JY, Zhang KL, Wu YP, Liu BQ: Smoking and mortality from esophageal cancer in China: a large case-control study of 19,734 male esophageal cancer deaths and 104,846 living spouse controls. Int J Cancer 2006, 119:1427-1432.

4. Largiader F: [Esophagus carcinoma]. Helv Chir Acta 1984, 50:541-549.

5. Siewert JR, Brucher BL, Stein HJ, Fink U: [Esophagus carcinoma--systemic or local risk of recurrence--which perioperative measures are successful?]. Langenbecks Arch Chir Suppl Kongressbd 1998, 115:290-294.

6. Schilling MK, Buchler MW: [Esophagus carcinoma: radical concepts]. Ther Umsch 1998, 55:435-438.

7. Layke JC, Lopez PP: Esophageal cancer: a review and update. Am Fam Physician 2006, 73:2187-2194.

8. Deschamps C, Nichols FC, Cassivi SD, Allen MS, Pairolero PC: Long-term function and quality of life after esophageal resection for cancer and Barrett's. Surg Clin North Am 2005, 85:649-56. xi

9. Law S, Wong J: Changing disease burden and management issues for esophageal cancer in the Asia-Pacific region. J Gastroenterol Hepatol 2002, 17:374-381.

10. Hayes JD, Flanagan JU, Jowsey IR: Glutathione transferases. Annu Rev Pharmacol Toxicol 2005, 45:51-88.

11. Sheehan D, Meade G, Foley VM, Dowd CA: Structure, function and evolution of glutathione transferases: implications for classification of non-mammalian members of an ancient enzyme superfamily. Biochem J 2001, 360:1-16.

12. Allocati N, Federici L, Masulli M, Di IC: Glutathione transferases in bacteria. FEBS J 2009, 276:58-75.

13. Goto S, Kawakatsu M, Izumi S, Urata Y, Kageyama K, Ihara Y, Koji T, Kondo T: Glutathione S-transferase pi localizes in mitochondria and protects against oxidative stress. Free Radic Biol Med 2009, 46:1392-1403.
14. Steele VE, Kelloff GJ, Balentine D, Boone CW, Mehta R, Bagheri D, Sigman CC, Zhu S, Sharma S: Comparative chemopreventive mechanisms of green tea, black tea and selected polyphenol extracts measured by in vitro bioassays. Carcinogenesis 2000, 21:63-67.

15. Deakin M, Elder J, Hendrickse C, Peckham D, Baldwin D, Pantin C, Wild N, Leopard P, Bell DA, Jones P, Duncan H, Brannigan K, Alldersea J, Fryer AA Strange RC: Glutathione S-transferase GSTT1 genotypes and susceptibility to cancer: studies of interactions with GSTM1 in lung, oral, gastric and colorectal cancers. Carcinogenesis 1996, 17:881-884

16. Chenevix-Trench G, Young J, Coggan M, Board P: Glutathione Stransferase $\mathrm{M} 1$ and $\mathrm{T} 1$ polymorphisms: susceptibility to colon cancer and age of onset. Carcinogenesis 1995, 16:1655-1657.

17. Seidegard J, Pero RW, Markowitz MM, Roush G, Miller DG, Beattie EJ: Isoenzyme(s) of glutathione transferase (class $\mathrm{Mu}$ ) as a marker for the susceptibility to lung cancer: a follow up study. Carcinogenesis 1990, 11:33-36.

18. de Bruin WC, Wagenmans MJ, Peters WH: Expression of glutathione Stransferase alpha, P1-1 and T1-1 in the human gastrointestinal tract. Jpn J Cancer Res 2000, 91:310-316.

19. Terrier P, Townsend AJ, Coindre JM, Triche TJ, Cowan KH: An immunohistochemical study of pi class glutathione S-transferase expression in normal human tissue. Am J Pathol 1990, 137:845-853.

20. Scharmach E, Hessel S, Niemann B, Lampen A: Glutathione S-transferase expression and isoenzyme composition during cell differentiation of Caco-2 cells. Toxicology 2009, 265:122-126.

21. Yu PF, Guo JM, Xu Q, Ying JE, Wang XJ, Cheng XD, Wang XB, Yu CD: [Significance of multidrug resistance gene-associated proteins in the postoperative adjuvant chemotherapy for gastric carcinoma and the prognosis.]. Zhonghua Wei Chang Wai Ke Za Zhi 2010, 13:289-293.

22. Arun BK, Granville LA, Yin G, Middleton LP, Dawood S, Kau SW, Kamal A, Hsu L, Hortobagyi GN, Sahin AA: Glutathione-s-transferase-pi expression in early breast cancer: association with outcome and response to chemotherapy. Cancer Invest 2010, 28:554-559.

23. Nelson WG, De Marzo AM, Deweese TL, Lin X, Brooks JD, Putzi MJ, Nelson CP, Groopman JD, Kensler TW: Preneoplastic prostate lesions: an opportunity for prostate cancer prevention. Ann N Y Acad Sci 2001, 952:135-144.

24. Kim SH, Kwon HC, Oh SY, Lee DM, Lee S, Lee JH, Roh MS, Kim DC, Park KJ, Choi HJ, Kim HJ: Prognostic value of ERCC1, thymidylate synthase, and glutathione S-transferase pi for 5-FU/oxaliplatin chemotherapy in advanced colorectal cancer. Am J Clin Oncol 2009, 32:38-43.

25. Usarek E, Kloniecki M, Osuch-Wojcikiewicz E, Bruzgielewicz A, Kukwa W, Kukwa A, Baranczyk-Kuzma A: [Expression of glutathione-S-transferase isoenzymes in larynx cancer]. Otolaryngol Pol 2004, 58:895-898.

26. Aliya S, Reddanna P, Thyagaraju K: Does glutathione S-transferase Pi (GST-Pi) a marker protein for cancer? Mol Cell Biochem 2003, 253:319-327.

27. Conklin DJ, Haberzettl P, Prough RA, Bhatnagar A: Glutathione-Stransferase $P$ protects against endothelial dysfunction induced by exposure to tobacco smoke. Am J Physiol Heart Circ Physiol 2009, 296:H1586-H1597

28. Gajewska B, Usarek E, Kazmierczak B, Kukwa W, Kukwa A, BaranczykKuzma A: [Expression of glutathione S-transferase isoenzymes in tongue and floor of mouth squamous cell carcinomas]. Pol Merkur Lekarski 2007, 23:196-199.

29. Ritchie KJ, Henderson CJ, Wang XJ, Vassieva O, Carrie D, Farmer PB, Gaskell $M$, Park K, Wolf CR: Glutathione transferase pi plays a critical role in the development of lung carcinogenesis following exposure to tobaccorelated carcinogens and urethane. Cancer Res 2007, 67:9248-9257.

30. Sasano H, Miuazaki S, Shiga K, Goukon Y, Nishihira T, Nagura H: Glutathione S-transferase in human esophageal carcinoma. Anticancer Res 1993, 13:363-368.

31. Okino ST, Pookot D, Majid S, Zhao H, Li LC, Place RF, Dahiya R: Chromatin changes on the GSTP1 promoter associated with its inactivation in prostate cancer. Mol Carcinog 2007, 46:839-846.

32. Ritchie KJ, Walsh S, Sansom OJ, Henderson CJ, Wolf CR: Markedly enhanced colon tumorigenesis in ApcMin mice lacking glutathione Stransferase Pi. Proc Natl Acad Sci USA 2009.

33. Chandra R, Haines GK, Bentz BG, Shah P, Robinson AM, Radosevich JA: Expression of nitric oxide synthase type 3 in reflux-induced esophageal lesions. Otolaryngol Head Neck Surg 2001, 124:442-447. 
34. Cobbe SC, Scobie GC, Pohler E, Hayes JD, Kernohan NM, Dillon JF: Alteration of glutathione S-transferase levels in Barrett's metaplasia compared to normal oesophageal epithelium. Eur I Gastroenterol Hepatol 2003, 15:41-47.

35. Monden N, Abe S, Sutoh I, Hishikawa Y, Kinugasa S, Nagasue N: Prognostic significance of the expressions of metallothionein glutathione-S-transferase-pi, and P-glycoprotein in curatively resected gastric cancer. Oncology 1997, 54:391-399.

36. Gaitanarou E, Seretis E, Xinopoulos D, Paraskevas E, Arnoyiannaki N, Voloudakis-Baltatzis I: Immunohistochemical localization of glutathione S-transferase-pi in human colorectal polyps. World J Gastroenterol 2008, 14:4179-4184.

37. Mavis CK, Morey K, Foster BA, Karpf AR: Expression level and DNA methylation status of glutathione-S-transferase genes in normal murine prostate and TRAMP tumors. Prostate 2009, 69:1312-1324.

38. Brabender J, Lord RV, Wickramasinghe K, Metzger R, Schneider PM, Park $J M$, Holscher AH, DeMeester TR, Danenberg KD, Danenberg PV: Glutathione S-transferase-pi expression is downregulated in patients with Barrett's esophagus and esophageal adenocarcinoma. $J$ Gastrointest Surg 2002, 6:359-367.

39. Peters WH, Wobbes T, Roelofs HM, Jansen JB: Glutathione S-transferases in esophageal cancer. Carcinogenesis 1993, 14:1377-1380.

40. Compton KR, Orringer MB, Beer DG: Induction of glutathione stransferase-pi in Barrett's metaplasia and Barrett's adenocarcinoma cell lines. Mol Carcinog 1999, 24:128-136.

41. Peng DF, Razvi M, Chen H, Washington K, Roessner A, Schneider-Stock R, El-Rifai W: DNA hypermethylation regulates the expression of members of the Mu-class glutathione S-transferases and glutathione peroxidases in Barrett's adenocarcinoma. Gut 2009, 58:5-15.

42. Huang JX, Li FY, Xiao W, Song ZX, Qian RY, Chen P, Salminen E: Expression of thymidylate synthase and glutathione-s-transferase pi in patients with esophageal squamous cell carcinoma. World J Gastroenterol 2009, 15:4316-4321

43. Fu B, Zhang Y, Wang Y: [Expression of GST-pi gene in human esophageal carcinogenesis]. Zhonghua Zhong Liu Za Zhi 1999, 21:29-31.

44. Eads CA, Lord RV, Wickramasinghe K, Long TI, Kurumboor SK, Bernstein L, Peters JH, DeMeester SR, DeMeester TR, Skinner KA, Laird PW: Epigenetic patterns in the progression of esophageal adenocarcinoma. Cancer Res 2001, 61:3410-3418

45. van Lieshout EM, Roelofs HM, Dekker S, Mulder CJ, Wobbes T, Jansen JB, Peters WH: Polymorphic expression of the glutathione S-transferase P1 gene and its susceptibility to Barrett's esophagus and esophageal carcinoma. Cancer Res 1999, 59:586-589.

46. Bastian PJ, Ellinger J, von RA, Muller SC, Yegnasubramanian S, Nelson WG, Stief CG: [CpG island hypermethylation of the DNA. Perspectives of a molecular biomarker for prostate cancer]. Urologe A 2008, 47:1205-1207.

47. Bernardini S, Miano R, lori R, Finazzi-Agro E, Palmieri G, Ballerini S, Angeloni C, Orlandi A, Bellincampi L, Cortese C, Federici G: Hypermethylation of the CpG islands in the promoter region of the GSTP1 gene in prostate cancer: a useful diagnostic and prognostic marker? Clin Chim Acto 2004, 350:181-188.

48. Nakayama M, Gonzalgo ML, Yegnasubramanian S, Lin X, De Marzo AM, Nelson WG: GSTP1 CpG island hypermethylation as a molecular biomarker for prostate cancer. J Cell Biochem 2004, 91:540-552.

49. Hibbs JB, Vavrin Z, Taintor RR: L-arginine is required for expression of the activated macrophage effector mechanism causing selective metabolic inhibition in target cells. J Immunol 1987, 138:550-565.

50. Duran WN, Breslin JW, Sanchez FA: The NO cascade, eNOS location and microvascular permeability. Cardiovasc Res 2010.

51. Lao-Sirieix P, Fitzgerald RC: Role of the micro-environment in Barrett's carcinogenesis. Biochem Soc Trans 2010, 38:327-330

52. Clemons NJ, McColl KE, Fitzgerald RC: Nitric oxide and acid induce double-strand DNA breaks in Barrett's esophagus carcinogenesis via distinct mechanisms. Gastroenterology 2007, 133:1198-1209.

53. Petit JF, Nicaise M, Lepoivre M, Guissani A, Lemaire G: Protection by glutathione against the antiproliferative effects of nitric oxide. Dependence on kinetics of no release. Biochem Pharmacol 1996, 52:205-212.

Pre-publication history

The pre-publication history for this paper can be accessed here:

http://www.biomedcentral.com/1471-2407/10/352/prepub doi: 10.1186/1471-2407-10-352

Cite this article as: Wang et al., Decreased expression of GST pi is correlated with a poor prognosis in human esophageal squamous carcinoma BMC Cancer 2010, 10:352

\section{Submit your next manuscript to BioMed Central and take full advantage of:}

- Convenient online submission

- Thorough peer review

- No space constraints or color figure charges

- Immediate publication on acceptance

- Inclusion in PubMed, CAS, Scopus and Google Scholar

- Research which is freely available for redistribution
C Biomed Central 